Sarah LeFanu

(D)https://orcid.org/0000-0002-4692-9267

\author{
Independent Scholar and Writer \\ Bristol, Great Britain
}

\title{
The Art of Rambling: Journeys through Space and Time with Mary Kingsley, Rose Macaulay, Ursula Le Guin, Naomi Mitchison and Octavia Butler
}

\author{
Sztuka włóczęgi: podróże w czasie i przestrzeni z Mary Kingsley, \\ Rose Macaulay, Ursulą Le Guin, Naomi Mitchison i Octavią Butler
}

Abstract: In "The Art of Rambling: Journeys Through Space and Time", Sarah LeFanu will look at the travels and travel-writings of, predominantly, Mary Kingsley and Rose Macaulay, and will boldly suggest some connections with the science fictional spacewomen and time-travellers of the second wave of feminism. She will talk about five travelling women whose lives span over one hundred years, and look at some of the connections between them in their lives and in their writing. By focusing on the experience of the five authors in a larger socio-cultural and literary context, LeFanu will trace the implications of writing and travelling vis-à-vis the intersectionality of one's personal commitments and motivations, with the aim to discovering how these are inflected by questions of gender and gender bias, consequently bearing upon the shape of modern discourses of women travel and travel writing. While each of the women travelled in different modes and to different places, for every one of them the imaginative worlds of their childhoods inspired them to engage with the world outside, an engagement that was not just personal but was also profoundly political.

Keywords: $\quad$ science fiction, time travel, feminism, women travellers

Abstrakt: W W niniejszym tekście Sarah LeFanu analizuje podróże i podróżopisarstwo przede wszystkim Mary Kingsley i Rose Macaulay, ukazując oryginalne powiązania między wymienionymi autorkami a podróżniczkami w czasie i przestrzeni kosmicznej znanymi z literatury science fiction drugiej fali feminizmu. LeFanu przygląda się również trzem innym podróżniczkom, poszukując wspólnego mianownika dla ich doświadczeń i pisarstwa w szerszym socjokulturowym kontekście. Autorka bada implikacje między podróżą a relacją z niej w kontekście intersekcjonalności i różnych jej odmian, ze szczególnym uwzględnieniem kwestii płci i uprzedzeń wynikających ze stereotypowego postrzegania i przedstawiania ról płciowych, także w dyskursach kobiecego podróżopisarstwa. Mimo że każda ze wspominanych przez LeFanu autorek podróżowała w inny sposób i do rożnych miejsc - to dla każdej z nich impulsem do kontaktów ze światem zewnętrznym były dziecięce krainy wyobraźni. Relacje te nie miały charakteru tylko osobistego, ale wyrażały się także w zaangażowaniu politycznym.

Słowa kluczowe: science fiction, podróże w czasie, feminizm, podróżniczki 
In this present article I am going to talk about five travelling women whose lives span over one hundred years, and to look at some of the connections between them in their lives and in their writing. Two of my subjects - Mary Kingsley and Rose Macaulay - were travellers in the geographical sense. They left England to travel abroad and they sent back despatches, as it were, from the places they visited. Naomi Mitchison travelled abroad, too, but she was also, along with Ursula Le Guin and Octavia Butler, a traveller of the imagination. These last three, in other words, were writers of a particular form of travel literature that is more usually known as science fiction. Rather than crossing continents, although Mitchison did also do that, they journeyed through outer space, and through time.

What are the connections between these five women who were born into different times and different circumstances? Why and how did they travel? How important was the fact that they were women? How did their gender affect their travelling and inform their writing?

Mary Kingsley and Rose Macaulay were English writers and travellers. Kingsley was born in 1862, into the middle of the reign of Queen Victoria. She travelled in West Africa in the 1890s, and died in 1900, the year before Victoria's death. Macaulay was also born into the Victorian age, in 1881, but she lived well beyond it, through all the upheavals of the first half of the twentieth century. She set off on her last journey, to Turkey, in the 1950s. Both Mary Kingsley and Rose Macaulay identified strongly with their fathers. George Kingsley had trained as a physician, and he travelled the world as a private doctor to a series of wealthy English aristocrats, in whose company he reinvented himself as a gentleman naturalist and sportsman. Rose Macaulay's father - also George was a schoolmaster and then for a time an independent classical scholar, during which period the family lived in Italy, before, at last, he got the university post at Cambridge he had long coveted.

From their father, the Macaulay children heard stories from the Greek myths; they listened spellbound to tales of heroes and their quests, of voyages across the seas to unknown lands. The travellers' tales that George Kingsley brought back with him created a hunger in his daughter that, 
when he left home again, she assuaged by raiding his library. There she found a shelf of books about Africa: Richard Burton's and John Speke's narratives of their search for the source of the Nile, Burton's Two Trips to Gorilla Land (1876), an account of his journeys through the French Congo, and Henry Morton Stanley's story of meeting Dr Livingstone on the banks of the River Zambezi.

As a girl and young woman in late nineteenth-century England you could secretly identify as much as you liked with your father. You could let your imagination roam free in the foreign worlds he conjured up, and that later you read about for yourself. You could fantasize that you were as free as your father to travel and to study, and to experience the wider world in all its rich strangeness. But in the real world, when you became a grown-up woman, your fantasies would be revealed as precisely that: fantasies. In the real world women's lives were strictly circumscribed. Not only were Kingsley and Macaulay born into a society in which women did not have a vote, but Kingsley, born before the passing of the Married Women's Property Act of 1870, was brought up in a world in which married women were the property of their husbands. Unlike her father, Mary Kingsley would have had to overcome considerable obstacles had she wished to train as a doctor. ${ }^{1}$ Rose Macaulay stood no chance of following in her father's Cambridge footsteps. ${ }^{2}$

I would like to turn for a moment to look at the mothers of these two young women. If Mary Kingsley and Rose Macaulay identified imaginatively with their fathers, how did they view the lives of their mothers? Mary Kingsley's mother, also Mary, had been George Kingsley's cook. He married her only a few days before their daughter was born, thus bestowing legitimacy on the child in the nick of time. Mrs Kingsley

${ }^{1}$ Elizabeth Garrett Anderson became the first British woman licensed to practice as a doctor in 1865. She achieved this through exploiting a loophole in the regulations of the Society of Apothecaries, a loophole that the Apothecaries promptly closed.

${ }^{2}$ Two women's colleges, Girton and Newnham, were founded in 1869 and 1871, but their students were not officially recognized as members of the University. Cambridge finally admitted women to full membership only in 1948. 
promptly gave up cooking and housekeeping, moved out of the basement kitchen and up into the marital bedroom on the first floor, which, thereafter, she only rarely left. Her daughter Mary became nurse, companion and housekeeper; and starting as a voracious reader she went on to become almost entirely self-educated. Mary's father did dip his hand into his pocket on one occasion, to send her for a month or two to Germany to learn the language: he needed a translation of some German volumes for one of his never-completed projects. Meanwhile Mary's younger brother benefited from Arthur's Education Fund, the fund of money so named in Thackeray's great comic novel Pendennis to describe the amount set aside by English middle-class families - however impoverished their circumstances - in order to ensure their sons receive a gentleman's education. Arthur's Education Fund is one of the manifestations of patriarchal power and privilege interrogated by Virginia Woolf in her coruscating polemic Three Guineas (1938). During long nights at her sick, unhappy mother's bedside, Mary Kingsley, in her early twenties, expanded her reading to include the scholarly work of anthropologists such as James Frazer and E.B. Tylor. She read in the original the work of German ethnologists, and she taught herself Arabic.

When she was twenty-nine, Mary Kingsley's parents died within a few months of each other, and suddenly, at last, she was free. "It was in 1893," she wrote in her introduction to Travels in West Africa,

that for the first time in my life, I found myself in possession of five or six months which were not heavily forestalled, and feeling like a boy with a new half-crown, I lay about in my mind, as Mr Bunyan would say, as to what to do with them. 'Go and learn your tropics,' said Science. Where on earth am I to go? I wondered, for tropics are tropics, wherever found; so I got down an atlas and saw that either South America or West Africa must be my destination, for the Malayan region was too far off and too expensive (Kingsley 1897, 6).

If she had not been so quick to get down her atlas and to plan her first trip abroad, she would have found herself trapped at home as her 
brother's housekeeper, a role which he viewed as his natural entitlement, and as her natural duty. Every trip abroad that Kingsley made thereafter would involve time-consuming, wearying work on her part to get rid of her brother, to pack him off somewhere else.

Travel abroad offered an escape route from the constraints and restrictions that circumscribed the lives of middle-class women in late Victorian England, a time when married women were expected to act as angels in the house, and when unmarried women filled subservient domestic roles as spinster aunts, or carers for elderly parents, or unpaid housekeepers for bachelor brothers.

Rose Macaulay also looked after an invalid mother, and took considerably longer than Mary Kingsley to make the break from home. She had tasted the joys and freedoms of abroad at an early age: she was seven when the family left England - ostensibly in search of a cure for Mrs Macaulay's tuberculosis - and moved to a small village on the Ligurian coast of Italy. Here Rose and her sisters and brothers listened eagerly to their father's stories of heroes and monsters from Greek mythology, and in between whiles they ran barelegged along the beach and put out to sea in a rowing boat they named the Argo, after Jason and the Argonauts. Rose, the most bookish of the children, spent long afternoons up a tree in the orchard, reading stories of travel and adventure, such as The Swiss Family Robinson (1812) and The Coral Island (1857), and writing her own. The return to late-Victorian England at the age of thirteen was an unpleasant shock: thick stockings, button boots, hats and gloves, and the dreary round of paying social calls with her mother. Her father vanished into the depths of the university library.

In her early fiction Rose Macaulay re-created Italy as a paradise that offered physical, social and emotional freedoms unavailable in classbound, moralistic late-Victorian and Edwardian England. Her contemporary E.M. Forster was doing something similar. Two of Macaulay's early novels - The Furnace of 1907 and The Lee Shore of 1912 - published in the same few years as Forster's Italian novels Where Angels Fear to Tread (1905) and A Room with a View (1908) - are set on the Ligurian coast, which she represents, in The Lee Shore, as "an Eden, unimaginably 
sweet, aflame with oleanders and pomegranate blossom, and white like snow with tall lilies" (Macaulay 1912, 284).

It was not until she was in her forties, by then a successful prize-winning novelist, that Rose Macaulay really started travelling abroad. She was conducting a love affair with a married man, Gerald O'Donovan: travelling through France and Italy allowed them, quite literally, an escape from 'keeping up appearances', which is the title of one of her 1920s novels. O'Donovan died in 1941, and Macaulay, grief-stricken, found herself unable to write fiction. She re-invented herself as a travel-writer; she went to Spain and Portugal in search of their classical pasts and their more recent histories. Abroad became an escape again for her, this time an escape from her own public persona as a dry, witty, spinster lady, and an escape too from a grief to which she was unable to publicly lay claim. Travelling helped heal the wounds of grief: she returned to fiction and fused it with travel-writing in the final work of her long writing life, the rich and glorious The Towers of Trebizond, with its now-famous opening line: “'Take my camel, dear,' said my aunt Dot, as she climbed down from this animal on her return from High Mass" (Macaulay 1956, 3).

Travel for these two women offered a soul-sustaining escape from home. Both were still girls when they first experienced its liberating qualities: Macaulay in actuality on the Ligurian shore, Kingsley through the pages of books. Their curiosity, both intellectual and imaginative, was kindled by fathers who were themselves sufficiently unconventional and broad-minded to let their daughters range freely through their libraries, but not quite sufficiently broad-minded or unconventional to do anything practical that would help them escape from the gender expectations that hemmed - or chained - them in.

Neither Mary Kingsley nor Rose Macaulay wrote directly about gender inequality - indeed Mary Kingsley spoke openly of her disapproval of the struggle for women's rights - but in Rose Macaulay's fiction we meet over and again girls and young women who chafe against the prison-bars of women's social role: against domesticity and marriage and motherhood. Macaulay herself in her own life chafed at those prison-bars. By taking a married lover she escaped domesticity, the burden 
of housekeeping, of bearing and rearing children, of pleasing a husband and looking after a home. Such freedom may have come at some emotional cost, but it gave her the freedom to travel, and to write.

Many of the characters in Macaulay's novels carry androgynous names: girls called Cecil or Alix, for example, and boys too, young men called Kay or 'Margery', which is the affectionate nickname given to Peter Margerison, who wanders up and down the Ligurian coast in The Lee Shore, trying for a glimpse of his lost paradise. Most famously perhaps, Macaulay teases her readers by giving an ambiguously-gendered name - Laurie - to the first-person narrator of The Towers of Trebizond, and another one - Vere - to Laurie's lover. On the shores of the Black Sea, Laurie dreams about Jason and the Argonauts, legendary characters Macaulay had known from early childhood:

I wondered which of the Argo heroes I was, but I could not remember, and I did not know if I was a hero or one of their mistresses, for they must have brought some of these, since the mistresses of heroes used to go everywhere about the world with them, and were in every army and every ship (...) (Macaulay 1956, 169).

Macaulay was in her seventies when she travelled to Turkey. She had not forgotten the freedoms she had enjoyed on the Mediterranean shore, before she entered the gendered world of English womanhood. A hero or one of their mistresses: Laurie isn't sure whether she is male or female, which is perhaps a way of being neither.

Virginia Woolf, knowing nothing of Rose's longstanding secret love affair, said of her friend and rival: "Poor dear Rose, judging from her works, is a Eunuch" $(1980,497)$. Perhaps that was an impression that Rose was content to give, freeing her as a female man, to borrow a phrase from the science fiction writer and literary critic Joanna Russ, to step outside of gender.

Mary Kingsley, travelling in West Africa in the 1890s, came of course from a much more rigidly gendered world than did the Rose Macaulay of the 1940s and 50s. The few white women who lived in West Africa 
were either missionaries or wives of colonial governors. Mary Kingsley was neither a missionary nor a wife. She allied herself with the white traders - all of them men. She travelled as a trader, and it was as a trader - someone to be negotiated with on an equal footing - that she met the chiefs and elders, both men and women, of the West African tribes. Sometimes she was trading for food, sometimes for artefacts or for the fishes and insects that she was collecting for the Natural History Museum in London; but most often, while her compatriots were trading for palm oil or rubber, she was trading for ethnographic knowledge, information on the traditional systems of belief and of law and justice that shaped West African lives.

Many of the West Africans she met and traded with, particularly amongst the tribes of the interior such as the Fang in French Congo, had never before seen a white woman. The men she employed to guide her through the forests and up and down the rivers of the interior called her 'Sir', or 'Sar'. None of them had ever met a 'Madam'.

In their travels both Mary Kingsley and Rose Macaulay positioned themselves ambiguously between or outside rigid notions of sexual difference. They recognized the freedom that such ambiguity offers, and how it sidesteps the question of the right to be a traveller (a right that was never questioned by George Kingsley). It sidesteps the question of authority.

In West Africa at the end of the $19^{\text {th }}$ century white authority was vested in the missionaries seeking to 'civilise' the natives and to save their souls for Christianity, and in the colonial officials seeking to control the natives and ultimately to own their labour for the Empire. Mary Kingsley was critical of both endeavours, the civilising one and the controlling one. Far from being on official business, sanctioned by church or state, she happened to find herself in West Africa after the death of her parents. Or so she claimed to a friend who was one of those colonial officials. She wrote to him: "I went down to West Africa to die. West Africa amused me and was kind to me and was scientifically interesting and did not want to kill me just then - I am in no hurry. I don't care one way or the other for a year or so" (Kingsley 1899, 133). Note the appar- 
ently artless 'and', 'and', 'and'. Note 'I don't care one way or the other (...)'. Often Kingsley would use the phrase 'puddling about' to describe what she was doing on the beaches and rivers of West Africa.

Fifty years later, and in a similarly apparently casual fashion, Rose Macaulay threw a handful of history books onto the back seat of her little car - her Morris Minor - and set off for Spain, with no grand itinerary nor great intentions, just to follow the coast, as Mary Kingsley followed the rivers, both of them taking to the water to swim when opportunity offered and no-one was around to watch. When the novelist Anthony Powell ran into Rose Macaulay in Italy a few years later - she was in her seventies by then - and asked, what on earth are you doing here?, she replied: "Oh, me? I'm just on my way to the Black Sea" (Powell 1972, 232-233), as if it were some kind of happenchance rather than a research trip for her next novel.

The Turkey of that novel, The Towers of Trebizond, is overrun by pushy young Englishmen busily gathering material for the 'Turkey books' they are going to get published. Meanwhile, the narrator Laurie is directionless, prone to feverish or drug-induced dreaming, caught up in a mosaic of cultural misunderstandings.

The apparently artless was something that both Mary Kingsley and Rose Macaulay developed with considerable skill, or artfulness, both in terms of how they presented themselves as travellers, and also how they wrote about their travels. They became skilled in what I would call the art of rambling.

In Travels in West Africa Kingsley is forever taking the reader off on a digression, for which she humbly apologises; she quotes from diary entries (or what she tells us are diary entries) and apologises for those, too: "I must pause here," goes one example,

to explain my reasons for giving extracts from my diary, being informed on excellent authority that publishing a diary is a form of literary crime (...). Many pages in my journals that I will spare you display this crime to perfection. For example: 'Awful turn up with crocodile about ten - Paraffin good for over-oiled boots - Evil spirits crawl on ground, hence high lin- 
tel - Odeaka cheese is made thus (...)' Then comes half a yard on Odeaka cheese-making (Kinglsey 1897, 100).

Scatty, disorganized, humble, apologetic: Kingsley herself mocks and exploits these hallmarks of a feminine sensibility.

Travels in West Africa was hugely popular, as indeed were the public talks Mary Kingsley gave, feeding as they did into an appetite in England for exotic tales from distant parts of the Empire. Behind the disguise of a feminine structurelessness and amateurishness, behind the disguise of rambling traveller and rambling writer, she became an authority on West Africa. For Mary Kingsley travel abroad brought not only the life she had dreamed of and yearned for but also the opportunity to write and to be published. In a world where power lay firmly with the patriarchy, Mary Kingsley cunningly and obliquely assumed a position of authority while artfully denying she was doing so.

In The Towers of Trebizond Rose Macaulay breathlessly piles phrase on top of phrase with 'and' and 'and' and 'and', just as Mary Kingsley did in her letter to the colonial official. Here is Laurie describing her return to the Black Sea with her Turkish friend Halide, after Aunt Dot and Father Chantry-Pigg have disappeared over the border into Russia:

It was melancholy to turn our backs on the mountain lake, and on the mountains and lakes beyond it, and on all the Armenian places we had hoped to see, such as Kars and Ani and Ararat (...) and the splendours and islands and fishing and Armenian churches of Lake Van (Macaulay 1956, 127).

"I adopted for Laurie," Macaulay wrote to a friend, "a rather goofy, rambling prose style" $(1962,232)$. In fact the goofy, rambling prose style was one that she would adopt for herself in her travel-writing, an artlessness that has often been associated with women's writing, the apparent artlessness or goofiness of diary entries and letters to friends, for example. Is this a way of slipping beneath the radar? Of thinking, and writing, outside of the - often hostile - male gaze? 
Rose Macaulay went to Spain and Portugal when she was in her sixties. Beneath the rambling chatty prose of the books she wrote about her Iberian travels - Fabled Shore (1949) and the two volumes of They Went to Portugal (1946) - lies a bedrock of research and scholarship that shows her to be as much an intellectual authority as was the father she had so looked up to.

My other three subjects, Ursula Le Guin, Naomi Mitchison and Octavia Butler, were practitioners of a different kind of travelling and travel-writing. Travel as a means of escape for women, and as a way to reinvent the female self in worlds where femaleness carries different meanings, has always been a central trope of feminist science fiction. All science fiction asks the question: what if? Some of the questions that feminist science fiction asks are: what if biological sex was fluid rather than polarised? What kind of society would develop? What kinds of individuals would live in that society?

I came across these questions for the first time when in the early 1970s I read Ursula Le Guin's The Left Hand of Darkness (1969), with its central question: what if people were hermaphrodites, sometimes male, sometimes female, otherwise sexless? In The Left Hand of Darkness an envoy from earth, a man called Genly Ai, is sent to the planet of Gethen. He arrives holding firmly to the belief that the binary gender system that prevails on planet earth is the universal norm, and so he is deeply unsettled by the people he meets on Gethen, the men - apparent men - who are unnervingly feminine - and the women - the apparent women who seem to the envoy to be inappropriately masculine. He is deeply unsettled to hear that the king is pregnant. But by the time he leaves the planet it is his own rigid, narrow masculinity that is in doubt. From being a stranger in a strange land, he becomes a stranger on the old, familiar planet of earth, looking at the binaries of gender and sexuality with a fresh eye. He has adopted the perspective of the Gethenians.

Le Guin's novel opened my eyes to so many questions, about the position of women within our culture, about sexuality, about the power of the patriarchy. I discovered that in science fiction we travel not just to escape from the limitations of the real, mundane world, but also to be 
able to look back at it from a distance, from that other place, and to see it afresh. ${ }^{3}$ I went on to work in a feminist publishing house in London called The Women's Press, where, just a few years later, we launched a feminist science fiction list with an anthology of short stories called Despatches from the Frontiers of the Female Mind (1985).

During the 1980s we published around forty titles in the science fiction list, some of them new books, some of them reprints from the 1960s and 1970s, and some, for example Herland (1915) by Charlotte Perkins Gilman, from much earlier. Looking back now, I realise that many of the titles could pass as titles of travel books: not only Despatches from the Frontiers and Herland, but also Sally Miller Gearhart's The Wanderground (1978), Joan Slonczewski's A Door into Ocean (1986), The Hidden Side of the Moon (1987) by Joanna Russ (author of the classic The Female Man (1975), to which I referred earlier), Suzette Haden Elgin's Native Tongue (1984), Suzy McKee Charnas's Walk to the End of the World (1974). ${ }^{4}$

I also realise, looking back at what I was working on in the 1970s and 1980s, that my interest in women travellers and their writing is something that began for me way back then, with those spacefaring and time-travelling women.

I am now going to look at two of those science fiction/travel books that we published at The Women's Press: Memoirs of a Spacewoman by Naomi Mitchison and Kindred by Octavia Butler, and consider some points of connection I believe they have with the travel-writing of Mary Kingsley and Rose Macaulay.

Like Mary Kingsley, the Scottish writer Naomi Mitchison, who was born in 1897 - the year in which Kingsley's Travels in West Africa was pub-

${ }^{3}$ The first piece of writing I ever had published was an article on Le Guin's The Left Hand of Darkness and The Dispossessed, in the British feminist magazine Spare Rib (LeFanu 1975, 40-2).

${ }^{4}$ Travel - in spaceships and before that in hot air balloons - has always been a staple of mainstream SF; feminist SF focuses on what it means to be a woman traveller. For another example of crossover in SF/travel titles, see the collection of essays on women and science fiction edited by Lucie Armitt: Where No Man Has Gone Before (1991). 
lished - grew up with strong male role-models. Both her father and her elder brother (John Scott Haldane and J.B.S. Haldane) were well-known scientists. Although she was allowed to attend a boys' preparatory school up to the age of twelve, she then fell foul, as Mary Kingsley had done, of Arthur's Education Fund. She became home-taught and self-taught. Her first publication was a scientific paper on the genetics of mice, co-authored with her brother when she was only eighteen. During the course of her long life - she died in 1999, at the age of a hundred and one - she published ninety books or so, in all genres and on a wide range of subjects.

Naomi Mitchison also travelled widely, and built up a special relationship with the Bakgatla people of Botswana in southern Africa, who honoured her by making her a Mmarona, an honorary tribal mother. In Mitchison we meet yet another artful female rambler. In her eighties she published a memoir of her travels under the title Mucking Around (1981); first cousin, surely, to Mary Kingsley's 'puddling about'.

The role of women scientists, and the question of whether women scientists approach their work differently from the way that men do, and if so in what way, interested Naomi Mitchison. She explored these questions in a number of her novels, and nowhere more directly than in her first science fiction novel, Memoirs of a Spacewoman (1962), which was written in the early 1960s and republished by us at The Women's Press twenty years later. Memoirs could stand as an example par excellence of science fiction as travel writing. Just as Mitchison gave the subtitle Five Continents over 50 Years to her travel book Mucking Around, so she could have given to her science fiction novel Memoirs of a Spacewoman the subtitle Five Planets over 50 Light Years. The spacewoman memoirist, Mary, is a linguist and an expert in communicating with strange and often unnerving alien life forms. Human forays to other worlds are underpinned by a strict code of non-interference, but emotional and erotic entanglements cannot always be avoided. And if Mary and her female colleagues seem better at communicating with other cultures and other life forms than are the male scientists, so perhaps their empathy for others - and is this a female trait? is a question that Mary asks herself - undermines or weakens their scientific detachment. 
Martians use their sexual organs not just for sex but also for non-sexual communication. Thus, after a near fatal crash on one of their trips, when one of Mary's Martian counterparts communicates closely with her to help her recover from her injuries, Mary becomes pregnant. She gives birth to a half-Martian, half-human daughter.

Hybridity - sexual, racial, or between species - interests many feminist science fiction writers: it is as if their travels through space and time inspire them to challenge not just the old familiar binaries of male and female, but also the binaries of human and other, or alien. Mary the spacewoman's relationship with Vly the Martian is just one of a number of her experiments in sexuality and indeed in motherhood that she recounts in her memoirs. Not all of these experiments are with aliens. Sex with humans brings its own problems, not least because of the time distortions experienced by space travellers. You start a relationship on planet earth with someone your own age and when you return from your next tour you may find yourself only a few months older than when you left, but he is now old enough to be your grandfather.

While her children are babies the spacewoman spends time on earth growing old at a normal rate. But the pull of elsewhere is strong. Soon she climbs aboard her spaceship again to escape the remorseless march of earthbound chronology, and also to have adventures and to enjoy - as does the envoy from earth in Le Guin's The Left Hand of Darkness - the liberating effects of travelling amongst other cultures, amongst other species.

The distortions, and paradoxes, thrown up by time travel are central to Octavia Butler's 1979 novel Kindred. Butler was born on the west coast of America in 1947, into a society that she saw at an early age was profoundly racially divided. As a small child she would accompany her mother to the houses where she worked as a housemaid: the quiet and observant girl noticed that white people employed black servants, and that those black servants always came and went by the back door. She found her wider world, just as Mary Kingsley and Rose Macaulay had done, through books; but where Kingsley and Macaulay, as middle-class English girls, came to reading through books belonging to their fathers, 
Butler, poor and black, found her reading in public libraries. She knew early on that she wanted and needed to write. Unlike other aspirational black girls of her generation who saw training as a teacher or a nurse as a path to autonomy, Butler bravely chose to work at casual labouring jobs that would give her the freedom to carry on thinking, imagining and writing.

Octavia Butler found her way on to writing courses where she met and was encouraged by some of the older, male, science fiction writers (Harlan Ellison and Samuel R Delany in particular) and she went on to win a number of literary prizes. She became best-known for her two series of novels, the Patternmaster series and the Xenogenesis trilogy. The latter grew from her award-winning 1984 story Bloodchild, her "pregnant man story" (Butler 1995, 30). ${ }^{5}$ Themes of cross-over, of inter-breeding, of hybridity, recur in Butler's fiction. She saw her own career as a writer in terms of hybridity, or what is more commonly called intersectionality, claiming she could always count on three loyal audiences: black readers, science fiction fans, and feminists (Kilgore and Samantrai 2010).

The narrative form of Kindred is very different from that of Mary Kingsley's and Rose Macaulay's travellers' tales, and also from that of Mitchison's Memoirs of a Spacewoman. There is no rambling in it, either artless or artful. The story of Kindred is shaped by necessity, rather than by the chance encounters that appear to shape Mitchison's Memoirs of a Spacewoman. Kindred's protagonist Dana is a time-traveller rather than a space-traveller. Although Dana has no control over when she travels back through time, she travels with an explicit purpose. Butler constructs the novel around an intriguingly paradoxical premise, one that has been explored over the years by a number of science fiction writers. If her protagonist does not return to the past and ensure that certain events do or do not occur, then she herself will never be born. Dana travels back through time because she has to. Therein lies the necessity. It becomes a question of survival, of very existence.

${ }^{5}$ Butler does not say so, but I take this to be a nod to Le Guin's pregnant king in The Left Hand of Darkness. 
Dana travels back to the days of slavery in the Deep South of America in order to save, over and over again, the life of her great-grandfather, and thus ensure her own birth three generations later. She is the descendant, she discovers, of a black slave and a white slave-owner. This latter is the man whose life she must save in order to come into existence herself. Time travellers, like physical travellers, enter and leave a place, and like physical travellers, they often return, again and again. Like physical travellers, too, they leave traces of themselves. They change the places and the people they encounter, and they themselves are changed.

Dana's journeys become for her, and for us the readers of the novel, an investigation into what African Americans had to do in order to survive slavery, and an investigation into the legacy of slavery. The travel undertaken in this novel offers no escape for its heroine, Dana, but it does offer her the opportunity to meditate on racial politics, then and now, and to challenge the status quo by raising questions about power and powerlessness, and about oppression and the possibilities of resistance. "I began writing about power," Octavia Butler once explained, referring to her whole oeuvre and not just this one novel, "because I had so little" (Goodreads n.d.). ${ }^{6}$

To conclude, I would like to cast a line - a rope-bridge perhaps - from Octavia Butler back to Mary Kingsley. "I had so little power," (Goodreads n.d.) said Butler, and the same was true of Mary Kingsley when she was a girl. Yet both of them became widely-read writers, writers who exercised a considerable power. What they also had in common in their girlhoods, besides a feeling of powerlessness, was a hungry curiosity and a rich imagination; they may have travelled in different modes and to different places, but for both of them the imaginative worlds of their childhoods inspired them to engage with the world outside, an engagement that was not just personal but was also profoundly political. I salute the courage of all five of these travelling women - Kingsley, Macaulay, Le Guin, Mitchison, Butler - and thank them for the despatches that they send back to us earthlings from the frontiers, wherever those frontiers may be.

${ }^{6}$ Widely quoted, rarely referenced. 


\section{References}

Armitt L., ed., 1991, Where no man has gone before, London: Routledge.

Babington Smith C., ed., 1962, Last letters to a friend from Rose Macaulay, 1952-1958, London: Collins.

Babington Smith C., 1972, Rose Macaulay, London: Collins.

Ballantyne, R.M., 1858, The coral island, London: T. Nelson \& Sons.

Burton, R., 1876, Two trips to gorilla land, London: Sampson \& Low.

Butler O., 1979, Kindred, New York: Doubleday.

Butler O., 1995, Bloodchild and other stories, New York: Four Walls Eight Windows.

Charnas S.M., 1974, Walk to the end of the world, New York: Ballantine.

Elgin S.H., 1984, Native tongue, New York: Daw.

Forster E.M., 1905, Where angels fear to tread, Edinburgh: William Blackwood \& Sons.

Forster E.M., 1908, A room with a view, London: Edward Arnold.

Gearhart S.M., 1978, The wanderground, London: Persephone.

Gilman C.P., 1915, Herland, London: The Women's Press.

Goodreads, n.d., Octavia Butler quotes, https://www.goodreads.com/quotes/8703112i-began-writing-about-power-because-i-had-so-little [accessed on: 24 August 2020].

Green J., LeFanu S., eds., 1985, Despatches from the frontiers of the female mind, London: The Women's Press.

Kilgore D.W.D., Samantrai R., 2010, A memorial to Octavia E. Butler, "Science Fiction Studies", no 37/3, 353-361.

Kingsley M., 1897, Travels in West Africa, London: Macmillan.

Kingsley M., 1899, Letter to Matthew Nathan, 12 March 1899, Bodleian Library, Ms Nathan.

Le Guin U.K., 1969, The left hand of darkness, New York: McDonald.

Macaulay R., 1907, The furnace, London: John Murray.

Macaulay R., 1912, The lee shore, London: Hodder \& Stoughton.

Macaulay R., 1946, They went to Portugal, London: Jonathan Cape.

Macaulay R., 1949, Fabled shore, London: Hamish Hamilton.

Macaulay R., 1956, The Towers of Trebizond, New York: Collins.

Macaulay R., 1962, Letter to Hamilton Johnson, in: Babington Smith C., ed., Last letters to a friend from Rose Macaulay, 1952-1958, London: Collins. 
Mitchison N., 1962, Memoirs of a spacewoman, London: Gollancz.

Mitchison N., 1981, Mucking around: Five continents over 50 years, Littlehampton: Littlehampton Book Services.

Powell A., 1972, The pleasures of knowing Rose Macaulay, in: Babington Smith C., Rose Macaulay: A Biography, London: Collins.

Russ J., 1975, The female man, New York: Bantam.

Russ J., 1987, The hidden side of the moon, New York: St Martin's.

Slonczewski J., 1986, A door into ocean, Westminster, Maryland, USA: Arbor House.

Woolf V., 1938, Three Guineas, London: Hogarth Press.

Woolf V., 1980, Letter to Hope Mirrlees, in: Nicolson N., Trautmann J., eds., The letters of Virginia Woolf, Vol. 6, 1934-1941, London: Hogarth Press.

Wyss J., 2021, The Swiss Family Robinson, Portland: Mint Editions.

SARAH LEFANU - PhD, independent scholar and writer, Bristol, Great Britain.

Sarah LeFanu is a British writer and biographer, whose books include Despatches from the Frontiers of the Female Mind (1986), In the Chinks of the World Machine: Feminism and Science Fiction (1988), Rose Macaulay: A Biography (2003) and its companion volume, Dreaming of Rose: A Biographer's Journal (2013) and S is for Samora: A Lexical Biography of Samora Machel and the Mozambican Dream (2012). Her latest work - Something of Themselves: Kipling, Kingsley, Conan Doyle and the Anglo-Boer War was published in 2020 by Hurst Publishers. Throughout the 1980s Sarah was an editor at The Women's Press, and was responsible for their ground-breaking feminist science fiction list. For many years she was a part-time tutor in the University of Bristol's Department for Continuing Education, and for the last five years has been a part-time tutor in the English Department, teaching English Literature and Community Engagement.

Brytyjska pisarka i biografka, autorka m.in.: Despatches from the Frontiers of the Female Mind (1986), In the Chinks of the World Machine: Feminism and Science Fiction (1988), Rose Macaulay: A Biography (2003) i drugiej części biografii Macaulay, Dreaming of Rose: A Biographer's Journal (2013) oraz S is for Samora: A Lexical Biography of Samora Machel and the Mozambican Dream (2012). Jej najnowsze dzieło pt. Something of Themselves: Kipling, Kingsley, Conan Doyle and the Anglo-Boer War zostało wydane w 2020 przez Hurst Publishers. W latach 80. XX w. LeFanu 
była redaktorką w The Women's Press, gdzie opracowała przełomową listę feministycznych pozycji science fiction. Przez wiele lat wykładała literaturę brytyjską i wiedzę o społeczeństwie na Uniwersytecie Bristolskim.

E-mail: sarah.lefanu@gmail.com 